\title{
Maori Hill-Forts
}

\section{by RAYMond FirTh, M.A.}

$\mathrm{M}$

ANY a wanderer through the country districts of New Zealand has found interest in the sight of the monumental earthworks which crown so many of our hills. There is something grand and yet pathetic about these old fortresses. Once the scene of turmoil and activity, they now lie neglected and still beneath the sky, clothed in bush, or scrub, or fern, or grass-grown and dotted with sheep. Their day is over, the Maori long since has ceased to swarm on their slopes and man their palisades ; they are but a memory of the warring and the peacemaking, the fighting and the feasting of the eventful past.

In this paper it is my object to give a brief account of the general features of their construction and of their importance in Maori life.

There were in olden days several kinds of permanent settlement which a Maori community might occupy. The specific types need not be enumerated here ; suffice to say that they can all be comprised under two heads : kainga, or unfortified villages, and $p a$, or fortified villages. All Maori settlements of the present day belong to the class of kainga, but it is to the pa maori, the old native fort, that I wish to confine my remarks.

Before engaging in a detailed discussion of the different types of fortification with their variant features, it will be convenient to set down in a brief space the main characteristics of such a stronghold. It was built upon a hill or ridge, or was backed on one or more sides by a cliff, a stream, or the sea. The natural means of defence which this afforded was supplemented by massive earthworks, commonly in the form of vallum and fosse. The fosse alone, or the scarped terrace, was an accompaniment or a substitute according to local conditions. Several lines of defence were constructed, each being surmounted by a stockade in such manner that the defenders, stationed immediately behind it, were enabled actively to ward off any assault. In some parts fighting stages overtopped the stockade, and allowed the defenders more easily to cast down spears, rocks and other missiles upon the enemy beneath. In each line of fortification was a narrow gateway- 


\section{MAORI HILL-FORTS}

larger $p a$ had subsidiary entrances as well-protected by a blind of palisading which exposed the foe to flank attack if he attempted to enter. Within the several lines of defence were dwelling-houses and storage huts for produce. The sections of the fort occupied by different family groups were often partitioned off, while behind the innermost fortification on the highest ground was the citadel of the stronghold, the site of the houses of the principal chief and his relatives, and the rallying point for all the people. Such is in essential the structure of the Maori hill-fort, though naturally local variants of all these points occur.

For comparative purposes it is interesting to note that the earthworks of the Maori stronghold are strongly reminiscent of the British hill fortress of the Stone, Bronze and Iron Ages. On the average, perhaps, the ramparts of these British forts, notably Eggardon and Maiden Castle, are of greater size than those of the Maori, and owing to the less rugged nature of the English countryside, they tend necessarily to be more elaborate. But to one who has spent many of his leisure summer days in roaming among the ditches, terraces and ramparts of the pa maori, the aspect of the British earthworks is by no means strange.

The function of these fortresses was apparently the same-to protect their inhabitants from external danger and to serve as dwelling places in normal life. In view of this fact their structural resemblance is noteworthy, raised as they were by the hands of people who are separated so widely by geographical situation, by cultural achievement, and by the span of the long-dead centuries. One needs to postulate no racial affinity nor far-flung cultural contact between the builders of these earthworks; the evidence warrants no such wild hypothesis of antipodal linkage. But to the British archæologist the description of a functionally cognate type of earthwork fortification may prove of interest, especially as the type of evanescent detail which has not been preserved for him in this country is still a matter of knowledge in New Zealand. The tools employed in fosse-digging, the structure of wooden stockades, the use of terraces, the relation of defence to water supply -on these and other points the description of Maori practice can perhaps initiate a fruitful comparison.

The $p a$ or fortified village was by no means the characteristic form of settlement throughout New Zealand. As a culture trait of any importance it is to be found almost solely in the North Island, a very few examples occurring south of Cook Strait. Moreover, in its most developed form of hill-fort with earthworks, with which we are here 


\section{ANTIQUITY}

concerned, it is very largely confined to the more northerly districts of this Island. Wellington, Hawkes Bay, Napier, do not display many examples, whereas in Taranaki, the Bay of Plenty, the Lower Waikato and the Auckland peninsula they seem to crown almost every prominent hill-top within sight.

It is possible that the distribution of $p a$ in New Zealand is indicative of some specific cultural influence, but the evidence at present is far too faint to support any theory. Moreover the prominence of the hill fortress in certain parts of the country cannot be attributed solely to the more warlike character of the inhabitants. The suitability of the soil for entrenching, its fertility as a source of crops (which greatly influences the population, also the desire for the land), the topography of the district, including the character of the vegetation, were important factors in determining the type of defensive warfare to be adopted.

It should be mentioned that these hill-forts vary greatly in age, some having been constructed only a few generations ago, while others have stood for several centuries.

The actual structural features of the pa maori may now be considered.

From the point of view of defence the situation of a fortified village is of extreme importance. Sloping ground, even if only of gentle gradient, confers a great advantage both in the construction of defensive works and the repelling of an assault. ${ }^{1}$

The Maori was by no means deficient in a knowledge of the principles of fortification, so that rarely if ever did he attempt to construct his $p a$ on open land, if an alternative site of any promise was available. Hill-top, cliff, headland, island or jutting crag-all of these were utilized by the native as sites for his defended villages, and some forts were rendered well-nigh impregnable from the outset by the judicious choice of an isolated precipitous rock pinnacle. Further vantage points of a similar kind were presented by the rugged western sea coast, from Taranaki northwards, and along the Auckland peninsula. A water-girded fort was always to be sought after, since it allowed of attack only by canoes or by swimming, hence islands, especially in lakes, were very popular as $p a$ sites. In some cases so urgent was the desire for defence of this type that artificial islets were constructed with

${ }^{1}$ See the excellent discussion of this point in Hadrian Allcroft, Earthwork of England, r908, pp. 162-7. 


\section{MAORI HILL-FORTS}

arduous labour, built up from the bed of the lake, and fortified with stockades. A particularly striking instance is the artificial islet Papawharangi, in the beautiful little lake of Papaitonga. This place was made by driving posts in a shallow of the lake, and sinking between them huge flax mats weighted with stones. Baskets of earth and piles of bracken were then heaped on top, together with other debris, more mats and stones were deposited above and the layer process continued until a substantial mound was raised.

At the present time the islet measures perhaps a score yards in diameter and stands about three feet above the water's edge.

In choosing the site of his $p a$, the Maori was an adept at seizing the advantage of the ground, and when building he was quick to utilize the natural barriers and incorporate them into the scheme of defence.

In a fortress with any pretensions to strength the primary place in the artificial defence system was usually held by earthworks.

These varied in character in different districts, and were adapted to the conformation of the site. Thus, for a headland, a ridge, or a spur, or on a gentle slope entrenchments were the rule, whereas on a rounded hill of steeper gradient such as the volcanic cones of the Tamaki isthmus, scarp and terrace were much in vogue. The most common type of fortification would seem to be the vallum and fosse, which characterized most of the forts of Taranaki, the Bay of Plenty, and the Waikato, and also occur in other localities. It is of interest to note that this was also the predominant type of defensive earthwork employed in the early fortresses of England. The Maori fosse was roughly rectangular or trapezoidal in cross section, the batters were fairly steep and often smoothed off to offer the minimum of foothold. In some cases the firmness of outline has been preserved, but nowadays the sides and edges of most of the old fosses have been broken down by erosion, tree roots, or the trampling of stock. As a general rule the material dug out of the fosse was piled up on the inner side to form the rampart. In this work some type of binding stuff was generally used ; brushwood of manuka scrub or the tops of bracken were the favourite materials. ${ }^{1}$

The rampart was made broad enough for the defenders of the $p a$ to stand upon it and wield their long thrusting weapons; it was essentially a structure to serve as an obstacle to assault, and to give the

${ }^{1}$ Best, The Maori, II, p. $32 \mathrm{I}$; S. Percy Smith, Maori Wars of the Nineteenth Century, rgro, p. 364. 


\section{ANTIQUITY}

occupants vantage of height and position, not to provide them with shelter from missiles.

Typical dimensions of a few of these earthworks may be given here to illustrate the range of achievement attained by these workmen of old with their primitive tools. A little fort examined by me some years ago at Tamahere in a bend of the Waikato river was defended by a single vallum and fosse, presenting in their eroded state a combined face of some 12 feet in height ; a similar small defended position jutting out from the heights above Muriwai beach was fortified by a single wall some 9 feet high and 3 feet broad on the top. These are but small fighting posts, and represent comparatively insignificant examples of the Maori art of fortification. In the larger $p a$ the ditch and rampart were often of great size. The accounts given of native forts by some of the earlier visitors to New Zealand are of especial interest in this connexion, since they saw these structures complete and often actually in use. Thus Cook mentions that the ditch and rampart of one $p a$ at Mercury Bay presented a wall 22 feet high, while the inner vallum and fosse of another fort occupied by people at the same place gave a total height of 24 feet, to which must be super-added the stockade, noted by Banks as being to feet high. ${ }^{1}$

If the fortified village was built on a ridge or a spur running off from a range of hills, then a rampart was often not constructed, but a simple fosse constituted the earthworks. This is the case with an ancient Maori fortress on the west coast of the Auckland peninsula. This $p a$, as $\mathrm{Mr}$ Geo. Graham has shown, ceased to be in permanent occupation after the middle of the eighteenth century, and so forms an excellent illustration of Maori fortification in pre-European times. ${ }^{2}$

The fortified portion of the village was built out on a spur overlooking the sea, which joins the main line of hills by a narrow ridge. The scheme of defence consists of three fosses transecting the ridge, the middle one being the main earthwork. The first fosse is $28 \mathrm{ft}$. long, $7 \mathrm{ft}$. deep, $18 \mathrm{ft}$. wide at the top and $7 \mathrm{ft}$. at the bottom. The second fosse, the principal line of defence, is a virtual gap cut in the saddle of the ridge. The outer face is not continuous from top to bottom, but is broken by a long step-like terrace $9 \mathrm{ft}$. down. This terrace, beginning with a breadth of $44 \mathrm{ft}$. and narrowing down

1 J. Cook, Account of a Voyage Round the World, Hawkesworth, I773, ii, pp. $34^{\circ}$ and $34^{2}$; Banks' Fournal, ed. by Hooker, 1896, p. 199.

2 Fournal Polynesian Society, I925, xxxiv, 19-23. 


\section{MAORI HILL-FORTS}

to about $16 \mathrm{ft}$., extends along for $5^{2} \mathrm{ft}$., after which comes the second drop of $12 \mathrm{ft}$., to the bottom of the ditch. There one is confronted by the inner face, a sheer scarp $30 \mathrm{ft}$. high. The fosse is $\mathrm{I} 6 \mathrm{ft}$. long, and as it falls away to a cliff at either end it can be seen what a formidable obstacle it was in olden days, when a palisade crowned the scarp and the defenders of the fort were massed above, ready to hurl down death on those who attempted to force the passage. ${ }^{1}$ The labour needed to dig out this terrace and trench must have been very great; at a rough calculation some 800 cubic yards of material have been scooped out from the ridge altogether. Further along the spur is another smaller trench, $32 \mathrm{ft}$. long, $12 \mathrm{ft}$. wide, and Io ft. deep, which represents the innermost line of defence, but which appears of little moment in comparison with the large fosse. All these three ditches cut right across the ridge from cliff to cliff.

On the Tamaki isthmus and in the vicinity of Auckland the combined vallum and fosse was not the predominant type of fortification. The scoria cones of this district appear to have lent themselves to scarping, and so we find terrace after terrace rising to the crown of the hill, looking from a distance like the stairways to a temple of the giants. These old volcanic landmarks, with tier upon tier of grassy platforms, each pitted with the hut sites and storage pits of a century ago are a picturesque sight. And standing on the crest of any of the larger of these forts and scanning the countryside, one can see the slopes of half a score of others, each terraced and scarped from base to crown. Their numbers give evidence of the teeming population that once tilled the soil of the isthmus, that fertile soil for which tribe fought tribe till the narrow neck of land received the name of Tamaki-makau-rauTamaki of a Hundred Lovers. ${ }^{2}$

Details vary according to the particular fort studied, but on the larger hills such as Mangere, Maunga-rei (Mount Wellington), Maungawhau (Mount Eden), and Ihumatao, the terraces are commonly 20 to $30 \mathrm{ft}$. wide, separated by a sloping bank or scarp of anything from ro to 40 or $50 \mathrm{ft}$. in height. Sometimes the terraces completely encircle the hill, at others they are broken up into short stretches or platforms resembling the lynchets of English slopes. The scarping of these hills for fortification purposes has been somewhat complicated by the

${ }^{1}$ For a full account of this fort with plan and photographs see the writer's paper "The Korekore $\mathrm{Pa}$," Fournal Polynesian Society, 1925, xxxiv, I-18.

In recent years the valuable researches of Mr Geo. Graham have thrown much light on the history of the isthmus and its hill-forts. 


\section{ANTIQUITY}

fact that they are extinct volcanic cones, and in most cases the deep funnel-like depression of the original crater still remains in the centre. Consequently the site is robbed of a broad expanse at the top of the hill which might serve as housing space. This restriction of available space for dwellings on the crest of the hill to a comparatively narrow band encircling the crater partly accounts, I believe, for the labour taken to excavate such broad platforms. That these terraces were thickly occupied is proved by the innumerable house-sites which pit them, and by the presence in some parts of great numbers of hearthstones, set on edge in the ground in the form of a rectangle to line the fireplaces of the former dwellings.

On volcanic hills where the lip of the crater has been broken through after the eruption a hollow or gully remains, and offers an easier ascent to the crest than up the main slope. The utility of this to potential attackers was perceived by the Maori and so he modified his defences accordingly. On Maunga-rei, Green Mountain, and other hill-forts near Auckland, one observes at such a spot not a continuity of terrace formation, but a series of short platforms or lynchets each Io or I 5 yards long and separated from its neighbour by a scarp of five or ten feet. These are so arranged that even should the foe make use of the easier gradient of the depression of the crater lip, he would not find himself within the line of palisades but would still have to face the cross stockades of numerous defended lynchets. A formed rampart is rare on these terraces, more often there is a slight slope of the terrace floor inward towards the centre of the hill. On the brink of each terrace a stockade was formerly set. The scarps of such terraces or ramparts were ascended by means of the usual Maori ladder, a single timber with notches cut therein; ditches were crossed by a rough draw-bridge constituted by a few planks.

On the use of stone in fortifications there is not much to be said, though it was sometimes adopted as a facing material for the scarp of terrace or fosse. Stone walls were sometimes built as at Te Tatua (Three Kings) or other places on the isthmus where the rocky surface favoured such a method.1 Again on the smaller of the Poor Knights Islands (Tawhiti Rahi) stone walls occur, and my friend Mr R. A. Falla (to whom I am indebted for a description and photograph) is of the opinion that they were probably used as defensive works. ${ }^{2}$

${ }^{1}$ Geo. Graham, Fournal Polynesian Society, 1921, xxx, 146.

2 Terraced forts with the scarps faced with stone have also been described from Rapa-iti, in the Pacific, by S. and K. Routledge, four. R.A.I., I92 I, li, 454-5. 


\section{MAORI HILL-FORTS}

In connexion with the earthworks of the Maori $p a$, reference may be made to the technical apparatus employed in excavation. This point is perhaps of some interest in view of the opinions expressed by British archæologists as to the nature of the tools used in the construction of the hill-forts of this country.

The tools of the Maori were simple but effective. In the work of excavation and removal of soil three processes must be undertaken ; the loosening of the earth, the gathering of it together, and the carrying of it away, and the Maori had a type of implement corresponding to each of these purposes. Elsdon Best, than whom none has a greater knowledge of the native, gives a short description of these tools, ${ }^{1}$ on which the following remarks are based. For loosening the earth the principal tool was the $k o$, the narrow-bladed, long-handled digging stick utilized in cultivating the soil for crops. A foot rest was lashed on the front of the shaft of the tool about 18 ins. from the point, and the foot pressed sideways on it, to give the weight in digging. In working at a $p a$ a short form of the implement was also employed. For loosening earth once the sod was removed a paddle-shaped tool about $2 \frac{1}{2} \mathrm{ft}$. long was used ; while for collecting together and clearing the loose soil from the trench a spade-like tool was used, or a form of shovel, having a rectangular blade with a rim at the sides. Two examples of shovelling implements, rimless, are in the British Museum, the one with a rectangular, the other with an almost semi-circular blade. Another type of implement also employed was scoop-shaped, somewhat like a canoe bailer. All these tools are of wood. When the earth had been scooped or shovelled up, it was put into baskets of native flax or wickerwork and taken up to form the rampart above the ditch. Such was the technique actually employed in excavation by the neolithic Maori of little more than a century ago. ${ }^{2}$

The massive earthworks of the Maori fortress were usually supplemented by less bulky structures of wood, which screened, crowned or

1 The Maori, II, 320-I.

2 Allcroft, $o p$. cit., p. $167 \mathrm{n}$. contrasts the skill in fortification of the Maori with their ignorance of other arts and crafts, and regards them as being a very primitive people. But material equipment alone should not be taken as the criterion of culture. In decorative art, music, poetry, the Maori had reached a high standard. It is quite incorrect to say of the Maori that "They were in fact, in the Palæolithic stage of culture." They were a neolithic people, well advanced in the arts of grinding, polishing, and drilling stone, even the pounamu, the green jade, which is known to modern lapidaries for its hardness. 


\section{ANTIQUITY}

overlooked them as the case might be. These were of two general types:- -stockades and fighting stages.

The stockade had many uses. It was erected on the top of a rampart, on the brink of a terrace or a cliff, on the outer face or counterscarp of a ditch, or stood alone on open ground. The general form of the stockade was that of an upright fence. Strong posts, even trunks of trees, two feet in diameter, were set deep in the earth two or three yards apart, and to them horizontal rails of saplings or split timber were lashed. To these again the palisades or battens of split wood were fastened vertically at intervals of a few inches by vine lashings. A fort might be defended by stockades alone, without the use of ramparts, but a $p a$ of the first rank was protected by ramparts, fosses, stockades, and fighting stages. According to the principles of Maori military engineering, such a place of importance might be expected to have four lines of stockades, each having its proper name and function. The outermost was a comparatively light structure, after the nature of an elevated screen; the supporting posts were of no great size, the battens were lashed to the horizontal rails but were not inserted in the ground. A gap of about a foot was left at the bottom, to enable the defenders behind the second stockade to wield their long thrusting spears with freedom. The second line of stockade stood two or three feet back and was more strongly built. Three horizontal rails were used as a rule, and these were lashed to the inner side of the posts. The battens were then lashed to these on the inside again. Thus the structure was of great strength, and on any force being exerted to pull down the battens, the strain was taken by the massive supporting posts. The lashing was done with pliant stems of the tough aka (a climbing plant) usually with a cross tie. ${ }^{1}$

The third line of stockade in such a fort was the main one. For this the supporting posts were twenty feet or more in height, set five feet or so in the ground. The upper part of the post was cut as a knob, or carved in the form of a human head or grotesque figure of terrific aspect, with glaring eyes and lolling tongue. The main gateway, opening in this line of stockade, was often hewn from one mighty baulk of timber. Within this again was the fourth or innermost stockade, of somewhat lighter construction.

1 The same material is employed to-day by the natives of certain forest districts, to lash their wooden fences. A native of Ruatahuna explained that the aka stems (of which several varieties are employed for different purposes) are cut some time before use, laid out in the open to dry and toughen and then steeped in cold water to render them supple. 


\section{MAORI HILL-FORTS}

Such are in native theory the stockade defences of a fully equipped fortress of the first rank. ${ }^{1}$ In actual fact, however, many varieties of this type occur, and the adaptation of earthworks to the contour of the ground involves many modifications of the stockade scheme. A reference to the actual defensive works of a few typical $p a$ of various kinds will indicate the variety of combination of earthwork and stockade employed, and the versatility of the Maori military engineer in turning to account the disposition of the ground.

On the terraced hill slopes of Maunga-rei, Matangi-nui, Raratonga - forts of the Tamaki-for instance, scarp and stockade alone were employed and a series of these, varying in number according to the size of the hill, constituted the defensive works of the stronghold. One of the $p a$ referred to above, as being seen by Captain Cook at Mercury Bay in 1769 , was situated on a headland, two sides of which were washed by the sea. The whole fort was enclosed by a stockade about ten feet high. On the landward side it was defended by a double ditch, the inner of which was backed by a rampart surmounted by this stockade. Another stockade was set on the outer brink of the ditch, so placed that it inclined inwards towards the fort. This somewhat unorthodox disposition of the stockade enabled defenders upon the ramparts to thrust down their spears without hindrance. The anonymous author of the fournal of a Voyage Round the World (pub. 1771), quotes a native chief to the same effect. This man explained that if the stockade pointed outwards, the enemy would find cover behind it, and could not be dislodged by the people in the $p a$ (p. 99). The interior of the fort was rising ground, and a series of terraces had been formed therein, each enclosed within separate walls of palisading. These enclosures communicated with one another by narrow lanes which could be easily stopped up. The only entrance to the pa was by a narrow passage $12 \mathrm{ft}$. long, which passed under a fighting stage. ${ }^{2}$

In I8I4 Nicholas entered a $p a$ at Rangihoua, Bay of Islands, which he describes as being defended by a wide and deep fosse with a stockade of great strength on the inner side. Palisaded enclosures divided off the huts, and carved "stiles" (of the nature of notched post-ladders) were used as a means of entry to them.

The house of the chief, as was customary, occupied the highest

\footnotetext{
${ }^{1}$ See the excellent description giving full native terminology by Best, The Maori, II, $321-31$.

2 Cook, op. cit., p. 340. Banks, op. cit. 199.
} 


\section{ANTIQUITY}

part of the hill. $\quad$ Another $p a$ on the south side of the Bay was defended by a fosse and vallum and then a stockade. To render the place still more inaccessible a great part of the hillside had been cut away and the face made quite precipitous. ${ }^{2}$ A stronger fort was that of Okuratope near Waimate, seen by Marsden and Nicholas in the same year. The first line of defence was a strong stockade of heavy posts $20 \mathrm{ft}$. high, the only entrance being a narrow opening $5 \mathrm{ft}$. high by $2 \mathrm{ft}$. wide. At a short distance from this came a "moat" at least $9 \mathrm{ft}$. broad, filled with water-an unusual mode of defence for the Maori-backed by a steep rampart on which stood another stockade of similar strength to the first. After an intermediate space of $80 \mathrm{ft}$. or so came a steep scarp about $15 \mathrm{ft}$. high, crowned by a third stockade that encircled the $p a$ and completed the defensive works. This $p a$ contained over I00 houses and store huts, and was occupied by 200 to 300 people. $^{3}$

The Manu-korihi $p a$ in Taranaki, surveyed in 1842 , displayed a triple line of major earthworks with a subsidiary ditch covering them in front. On two sides the $p a$ was protected by a cliff with the river flowing along part of its base, and here a stockade along the cliff edge sufficed. But on the open side came the earthworks, each of the three lines comprising a fosse, and behind it a rampart, crowned with a stockade. ${ }^{4}$

These few instances, drawn mainly from the accounts of early observers when the Maori $p a$ in all its strength still constituted an integral feature in the life of the people, indicate the difference in the methods of fortification, and the varied manner in which stockades were utilized as defensive works.

Wooden erections of the other type were also used in many forts as a basis for defensive operations. They were the fighting stages, elevated platforms $20 \mathrm{ft}$. or more in height, set on massive posts to overtop rampart or stockade. Banks (op. cit., p. 199) notes that one stage was $20 \frac{1}{2} \mathrm{ft}$. high, $6 \frac{1}{2} \mathrm{ft}$. broad, and $43 \mathrm{ft}$. long, while on it were laid bundles of spears and heaps of stones to be cast down for the discomfiture of the enemy beneath. These and similar stages were

1 Narrative of a Voyage to New Zealand, 1817, i, r74.

Ibid., pp. 269-7o.

3 Nicholas, op. cit., i, 336-7.

4. Hamilton, Maori Art, r896, p. 123 (plan).

Note.-Marsden, Missionary Register, Dec., I816, pp. 502-3, says in his description that there were three rows of trenches. This discrepancy may be partly due to his having included the scarp in this category. But if his account is correct then the pa was defended still more strongly than represented above. 


\section{MAORI HILL-FORTS}

also used by the watchman or sentry who in troublous times was posted there to give warning of the approach of an enemy. On this stage often hung a pahu, a large wooden slab suspended by cords after the manner of a gong, which gave out a resonant booming sound when struck, and served to warn the inhabitants of the fort and of the nearby countryside.

A few words may now be devoted to a discussion of the value of the $p a$ in warfare. The somewhat tedious description of the various types of defensive works has given some indication of the strength of these old forts and it is clear that many of them were almost impregnable to direct assault. Sometimes breaches were made in the palisades by pulling down battens with a bar and rope thrown over them, and fire was a weapon which reduced many a fortress. But very frequently other measures were necessary. Hence the many accounts we have in Maori tradition of surprise attacks - at daybreak, up little-used cliffpaths in the dark, in a storm when no sound of men's feet could be heard ; of masquerades of war parties as peaceful fishermen, as returning village people, or even as gigantic sea fish ; of treachery-a secret opening of gates, or a false peace and an unexpected return. Records of Maori warfare form a dark tale of ambuscades, stratagems, treachery and ferocity, mingled with a tactical ability and a rude chivalry that compel admiration. At times none of these ways of attack seemed feasible and the $p a$ was besieged.

Now practically all the cultivations of the people lay outside the fort, so that to be able to resist a siege stocks of provisions had to be kept inside the enclosure. Vegetable foods were stored in pits underground and flesh foods were dried and preserved in storehouses or on tall stages. But the weak point was usually lack of water. As a rule the hill-fort had no spring within it, and anyone venturing out to get water was cut off by the besiegers. In some forts attempts seem to have been made to keep an artificial supply. On occasions water was stored in gourds. Best ${ }^{1}$ describes and illustrates the use of underground pits as reservoirs for the precious fluid, while some of the bottle-shaped subterranean chambers at Korekore were probably utilized for the same purpose. ${ }^{2}$ But as a rule water storage was of a very elementary kind, and time and again a beleaguered fortress was taken or surrendered through lack of water. Nevertheless the siege was often a protracted affair, lasting for days or even weeks,

1 Dominion Museum Bulletin, no. 5, pp. 81 sqq.

${ }^{2}$ Firth, op. cit., pp. 9-Io. 


\section{ANTIQUITY}

while one blockade, the longest recorded, endured for seven months. ${ }^{1}$ Despite the preoccupation of this paper with the Maori $p a$ as a fortified position, it must not be imagined that it was purely a wartime dwelling. It was not only a military stronghold ; it was the home of the people, the centre of their social and economic life as well. Excluding a few defended posts on isolated rock pinnacles, which served as occasional retreats only in time of stress, the average Maori $p a$ was a place in permanent occupation. And the economic aspect of the settlement was not lost from view. The site, though primarily selected for its defensive character, was also chosen for its proximity to sources of food supply - to fertile soil, fishing grounds, or a forest where birds were plentiful. It is as the home of the people, the centre of their social and economic life, no less than as their defensive stronghold and the focus of their military activity that the Maori $p a$ has its peculiar interest for the archæologist, the anthropologist and the prehistorian.

In conclusion I wish to acknowledge my indebtedness to $\mathrm{Mr}$ Elsdon Best, on whose well-known writings I have drawn liberally at certain points in this paper. My thanks are also due to Mr O. G. S. Crawford for references to the literature of British earthworks and to my friends Mr and Mrs Philip Williams of Bridehead, Dorset, to whose kindly thought I owe my visits to Eggardon and Maiden Castle.

The literature on Maori hill-forts is scanty. The following list gives the more important papers dealing with the subject and also the relevant sections of more general works. Incidental references will be found in the footnotes of the foregoing article.

ELSDON BEST.-"Stockades and Earthworks in New Zealand." American Antiquarian, I895, xvii, I 54-6; The Maori, 1924, ii., ch. Xv, PP. 304-52 ; “The Pa Maori," Bulletin Dominion Museum, 1926, no. 6, Wellington. This is a fully documented and authoritative work with plans and illustrations.

RAYMOND FIRTH.--"The Korekore $\mathrm{Pa}$ : an ancient Maori Fortress." Fournal Polynesian Society, 1925, xxxiv, I-18.

A. Hamilton.-Maori Art. Dunedin, 1896, pp. 71-9; $121-9$.

W. H. SkInner. - "The Ancient Fortified Pa." Fournal Polynesian Society, I9I I, $\mathrm{xx}, 7 \mathrm{I}-7$.

S. PerCY SMith.- “ Maori History of the Taranaki Coast." Memoirs Polynesian Society, rgro, vol. $i$, passim (plans, photographs and descriptions of $p a$ ).

1 S. Percy Smith, History and Traditions of the Taranaki Coast, I9ro, p. 365. For other instances of sieges see Ibid. pp. $244,246,288$, etc.; also Best, op. cit., pp. 335-8. The occurrence of such sieges of $p a$ in Maori warfare is an interesting commentary on the opinion expressed by A. H. Allcroft (op. cit., p. 210 ), that " of sieges, and blockades, it is practically certain the prehistoric period knew nothing. A single rush, a succession of rushes, at most a day's assault, was all that was to be feared." Such was not the case with the neolithic Maori. 